\title{
APLIKASI EDUTAINMENT WAWASAN KEBANGSAAN BERBASIS ANDROID MOBILE PLATFORM
}

\author{
Nofiandri Setyasmara ${ }^{a}$ \\ ${ }^{a}$ Politeknik Negeri Media Kreatif, Jakarta
}

INFORMASI ARTIKEL

Sejarah Artikel:

Diterima Redaksi: 03 Februari 2020

Diterbitkan Online: 15 Juli 2020

\section{KATA KUNCI}

Aplikasi Edutainment, Aplikasi Android, MIT App Inventor

\section{KORESPONDENSI}

Email : nofiandri@ polimedia.ac.id

\section{A B S S T R A A C T}

Jumlah penggunaan perangkat bergerak dengan platform mobile Android di Indonesia sangatlah besar. Angka yang sangat besar tersebut belum diimbangi dengan kemampuan produksi dalam negeri baik dalam hal produksi perangkat kerasnya berupa smartphone dan tablet PC maupun dalam hal pengembangan aplikasinya khususnya aplikasi dengan konten lokal. Meningkatnya jumlah aplikasi Android yang bisa didapatkan secara daring umumnya didominasi oleh aplikasi hiburan khususnya dalam bentuk permainan (game). Jenis aplikasi yang tidak saja bersifat menghibur tetapi juga sekaligus memiliki fungsi edukasi khususnya dalam memberikan wawasan kebangsaan Negara Kesatuan Republik Indonesia (NKRI) masih sangatlah jarang. Dengan demikian penelitian rancang bangun aplikasi edutainment wawasan kebangsaan ini kiranya dapat menjadi solusi kreatif dalam meningkatkan kesadaran masyarakat Indonesia dalam berbangsa dan bernegara.

Aplikasi edutainment wawasan kebangsaan yang dibuat pada penelitian ini berupa aplikasi kuis dengan topik pertanyaan seputar wawasan dan pengetahuan tentang nasionalisme kebangsaan Negara Kesatuan Republik Indonesia (NKRI) mencakup konstitusi negara, sejarah bangsa, kekayaan budaya, dan kekayaan alam. Aplikasi kuis yang dibuat memiliki 2 (dua) tingkat kesulitan (level). Jenis pertanyaan pada tingkat kesulitan (level) 1 dirancang untuk memiliki tingkat kesulitan yang rendah dengan diberikan 2 (dua) buah kemungkinan jawaban yang benar yaitu menggunakan sistem pilihan ganda jawaban "Benar dan Salah". Sedangkan jenis pertanyaan pada tingkat kesulitan (level) 2 dirancang untuk memiliki tingkat kesulitan lebih tinggi dari pada tingkat kesulitan (level) 1 dengan diberikan 4 (empat) buah kemungkinan jawaban yang benar yaitu menggunakan sistem pilihan ganda jawaban “A, B, C, dan D".

\section{PENDAHULUAN}

Departemen Perdagangan Republik Indonesia, dalam Kajian Industri Kreatif, membagi industri kreatif menjadi beberapa subsektor yaitu: periklanan, arsitektur, pasar barang seni, kerajinan, desain, fesyen, video, film, fotografi, permainan interaktif, musik, seni pertunjukan, penerbitan dan percetakan, layanan komputer dan piranti lunak, televisi dan radio, riset dan pengembangan. Subsektor layanan komputer dan piranti lunak (software) termasuk subsektor yang mencakup area yang sangat luas. Hal ini dikarenakan layanan komputer dan piranti lunak dapat diimplementasikan untuk menunjang subsektor industri kreatif lainnya, bahkan juga untuk hampir semua sektor industri dan bidang kehidupan.

Pola hidup masyarakat di dunia dan di Indonesia pada khususnya telah mengalami perubahan yang sangat signifikan sejak diperkenalkannya teknologi mobile. Tidak dapat disangkal lagi 
bahwa perkembangan penggunaan perangkat mobile di dunia terus mengalami peningkatan yang signifikan dari tahun ke tahun.

Berdasarkan data dari IDC (International Data Corporation) yang merupakan salah satu perusahaan riset terkemuka di dunia, didapatkan data bahwa pertumbuhan smartphone dan tablet PC, yang termasuk dalam katagori mobile device, jauh mengalahkan pertumbuhan komputer desktop dan laptop/notebook baik dari aspek jumlahnya per tahun maupun kenaikannya.

Dari pertumbuhan mobile device di dunia yang sangat tinggi, ternyata Indonesia menempati urutan pertama dalam hal durasi penggunaan smartphone per harinya, bahkan jika digabungkan dengan penggunaan tablet PC. Dengan demikian Indonesia adalah negara dimana durasi penggunaan mobile device per harinya memiliki prosentase terlama di dunia.

Masih dari IDC juga didapatkan data prakiraan prosentase pangsa pasar sistem operasi smartphone di dunia pada tahun 2018 dimana sistem operasi Android masih tetap menguasai sebagian besar pangsa pasar tersebut yaitu sebesar 77,6\% pada tahun 2018. Dari beberapa data yang telah disebutkan di atas dapat ditarik benang merah bahwa angka penggunaan perangkat bergerak, baik berupa smartphone maupun tablet PC, khususnya yang menggunakan platform mobile Android, di Indonesia sangatlah besar disertai dengan adanya kecenderungan yang semakin meningkat tiap tahunnya.

Jumlah penggunaan perangkat bergerak dengan platform mobile Android yang sangat besar tersebut belum diimbangi dengan kemampuan produksi dalam negeri baik dalam hal produksi perangkat kerasnya berupa smartphone dan tablet PC maupun dalam hal pengembangan aplikasinya khususnya aplikasi dengan konten lokal. Meningkatnya jumlah aplikasi Android yang bisa didapatkan secara daring umumnya didominasi oleh aplikasi hiburan khususnya dalam bentuk permainan (game). Jenis aplikasi yang tidak saja bersifat menghibur tetapi juga sekaligus memiliki fungsi edukasi khususnya dalam memberikan wawasan kebangsaan Negara Kesatuan Republik Indonesia (NKRI) sehingga dapat meningkatkan kesadaran masyarakat Indonesia dalam berbangsa dan bernegara masih sangatlah jarang.

\section{TINJAUAN PUSTAKA}

\subsection{Mobile Platform Android}

Android adalah sistem operasi untuk mobile device yang awalnya dikembangkan oleh Android Inc. Perusahaan ini kemudian dibeli oleh Google pada tahun 2005. Android dibuat berdasarkan kernel Linux yang dimodifikasi. Android menyediakan platform terbuka bagi para pengembang untuk menciptakan aplikasi mereka sendiri untuk digunakan oleh bermacam piranti bergerak (Safaat, 2012).

\subsection{MIT App Inventor}

App Inventor adalah sebuah aplikasi web pemrograman visual open source yang digunakan untuk mengembangkan aplikasi mobile berbasis android dengan dukungan fitur drag and drop tool. Untuk mendesain sebuah user interface suatu aplikasi dapat dilakukan dengan menyusun komponen-komponen aplikasi menggunakan aplikasi web GUI builder. Selanjutnya behavior dari komponen-komponen tersebut didefinisikan menggunakan sederetan blok instruksi yang cara menggunakannya seperti puzzle.

App Inventor menggunakan Kawa Language Framework dan Kawa's dialect yang dikembangkan oleh Per Brother. Kedua aplikasi tersebut didistribusikan sebagai bagian dari GNU operating system oleh Free Software Foundation. Kedua aplikasi tersebut dijadikan compiler dan menerjemahkan visual block programming untuk diimplementasikan pada platform android (Wolber, 2011).

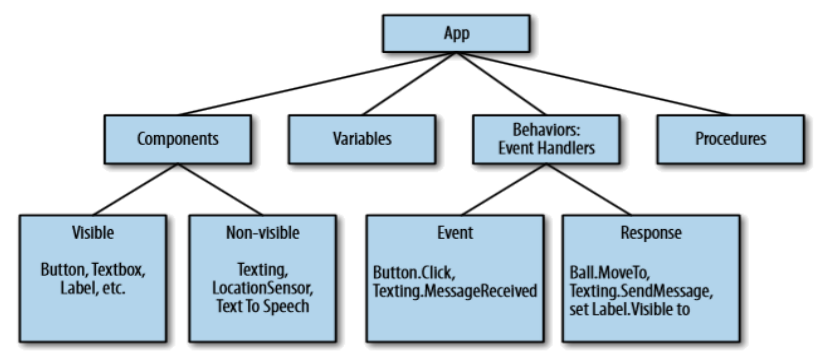

Gambar 1 Arsitektur Aplikasi MIT App Inventor

\subsection{Research and Development $(R \& D)$}

Penelitian ini bertujuan untuk merancang dan membuat sebuah sebuah aplikasi edutainment wawasan kebangsaan Negara Kesatuan Republik Indonesia (NKRI). Oleh karena itu, jenis penelitian yang tepat adalah penelitian research and development (R\&D). Menurut Sugiyono (2009), Research and Development (R\&D) adalah metode penelitian yang digunakan untuk menghasilkan produk tertentu, dan menguji keefektifan produk tertentu. Produk tersebut dapat dihasilkan dengan menggunakan penelitian yang bersifat analisis terhadap kebutuhan.Pengujian terhadap efektifitas dari produk tesebut dilakukan agar dapat digunakan oleh masyarakat secara luas.

\section{KONSEP PERANCANGAN}

Untuk menghasilkan produk berupa perangkat lunak (software) aplikasi edutainment wawasan kebangsaan Negara Kesatuan Republik Indonesia (NKRI), maka pelaksanaan penelitian research and development $(\mathrm{R} \& \mathrm{D})$ ini harus mengikuti langkahlangkah baku dalam pembuatan perangkat lunak (software), antara lain sebagai berikut :

a. System Engineering (Rekayasa Sistem)

Perangkat lunak merupakan bagian dari sistem yang lebih besar, maka pekerjaan dimulai dari pengumpulan data agar dapat diketahui elemen- elemen yang hendak dialokasikan ke dalam perangkat lunak. Hal ini penting dilakukan ketika perangkat lunak harus berkomunikasi dengan pengguna (manusia), perangkat keras (hardware), dan basis data. Rekayasa sistem dan analisis menekankan pada pengumpulan kebutuhan pada level sistem dengan sedikit perancangan dan analisis.

b. System Analysis (Analisis Sistem)

Pada tahap ini dilakukan analisa pemecahaan permasalahan dari data dan informasi yang telah didapatkan dari tahap penelitian yang sebelumnya, serta mengumpulkan kebutuhan-kebutuhan aplikasi edutainment wawasan 
kebangsaan Negara Kesatuan Republik Indonesia yang akan dibangun.

c. Design (Perancangan Sistem)

Ada 4 atribut untuk desain yaitu struktur data, arsitektur sistem, sistem prosedur dan tampilan antar muka. Proses desain mengubah kebutuhan- kebutuhan menjadi bentuk karakteristik yang dimengerti perangkat lunak sebelum dimulai penulisan program. Desain ini harus didokumentasi dengan baik dan menjadi konfigurasi perangkat lunak aplikasi edutainment wawasan kebangsaan Negara Kesatuan Republik Indonesia yang akan dibangun.

d. Coding (Pengkodean)

Setelah tahap perancangan (design) kemudian dilanjutkan dengan menerjemahkan desain yang telah dibuat menjadi bentuk yang dapat mengerti oleh komputer. Pada tahap ini digunakan MIT App Inventor sebagai sebuah IDE (Integrated Development Environment) untuk mengembangkan perangkat lunak yang dapat dijalankan platform mobile android.

e. Testing (Pengujian)

Setelah tahap pengkodean program telah dilakukan dan program dapat berjalan, maka tahap selanjutnya adalah tahap pengujian program. Pengujian memfokuskan pada logika internal dari perangkat lunak, fungsi eksternal dan mencari segala kemungkinan masalah selanjutnya memeriksa apakah perangkat lunak aplikasi edutainment wawasan kebangsaan Negara Kesatuan Republik Indonesia yang dibangun.tersebut sesuai dengan yang diharapkan.

f. Maintenance (Perawatan)

Pada tahap ini dilakukan perawatan terhadap perangkat lunak yang sudah jadi. Dalam penggunaannya akan masih terdapat potensi ditemukannya kesalahan (error) atau ada fitur baru yang perlu ditambahkan, sehingga perlu dilakukan pemeliharaan terhadap aplikasi edutainment wawasan kebangsaan Negara Kesatuan Republik Indonesia yang dibangun.

\section{HASIL DAN PEMBAHASAN}

\subsection{Perancangan Aplikasi}

Aplikasi edutainment wawasan kebangsaan Negara Kesatuan Republik Indonesia (NKRI) yang akan dibuat pada penelitian ini adalah berupa aplikasi kuis. Topik-topik yang digunakan untuk membuat pertanyaan adalah seputar wawasan dan pengetahuan tentang nasionalisme kebangsaan NKRI mencakup konstitusi negara, sejarah bangsa, kekayaan budaya, dan kekayaan alam dan sebagainya. Pertanyaan-pertanyaan yang ada di dalam aplikasi kuis dapat berupa teks, gambar maupun suara.

Aplikasi kuis yang akan dibuat memiliki 2 (dua) tingkat kesulitan (level). Pada setiap tingkat kesulitan (level) terdapat 10 (sepuluh) buah pertanyaan. Jenis pertanyaan pada tingkat kesulitan (level) 1 (satu) dirancang untuk memiliki tingkat kesulitan yang rendah dengan diberikan 2 (dua) buah kemungkinan jawaban yang benar yaitu menggunakan sistem pilihan ganda jawaban "Benar dan Salah". Sedangkan jenis pertanyaan pada tingkat kesulitan (level) 2 (dua) dirancang untuk memiliki tingkat kesulitan lebih tinggi dari pada tingkat kesulitan (level) 1 (satu) dengan diberikan 4 (empat) buah kemungkinan jawaban yang benar yaitu menggunakan sistem pilihan ganda jawaban “A, B, C, dan D”.

Skor yang didapatkan oleh pengguna setiap kali berhasil menjawab pertanyaan dengan benar adalah 10 (sepuluh). Untuk dapat berpindah ke tingkat kesulitan (level) 2 (dua) maka pengguna harus mendapatkan skor total sebanyak 100 (seratus). Dengan demikian pengguna harus menjawab semua pertanyaan yang ada pada tingkat kesulitan (level) 1 (satu) sebelum dapat melanjutkan pada tingkat kesulitan (level) 2 (dua). Selama pengguna tidak dapat mencapai skor total sebanyak 100 (seratus) pada tingkat kesulitan (level) 1 (satu) maka tombol untuk memilih pertanyaan pada tingkat kesulitan (level) 2 (dua) tidak akan aktif sehingga pengguna harus kembali menyelesaikan pertanyaanpertanyaan yang terdapat pada tingkat kesulitan (level) 1 (satu).

\subsection{Proses Pembuatan}

Sistem online database yang dibuat menggunakan layanan dari Google Cloud Platform. Program kustomisasi tinywebdb (online database) yang disediakan oleh MIT App Inventor ditulis dalam bahasa Phyton sehingga dibutuhkan instalasi Phyton yang dapat diunduh dari https://www.phyton.org dan Google App Engine SDK for Phyton dari https://cloud.google.com/appengine. Aplikasi online database yang dijalankan oleh server Google App Engine menggunakan URL: https://kbc-onlinedatabase.appspot.com/. Pada gambar 3 diperlihatkan tampilan online database yang telah berisi data harga dan tarif komponen biaya cetak.

Proses pembuatan aplikasi menggunakan MIT App Inventor terbagi menjadi 2 (dua) tahapan utama. Tahap pertama adalah tahap Designer, dimana tahap ini direpresentasikan oleh proses penggunaan bagian Designer untuk menentukan komponen apa saja yang diperlukan dalam aplikasi yang akan dibuat. Komponen adalah salah satu elemen dari arsitektur aplikasi yang dibuat menggunakan MIT App Inventor.

Tahap yang kedua adalah tahap Blocks Editor yang direpresentasikan oleh proses penggunaan bagian Block Editors untuk memrogram perilaku dari komponen-komponen yang telah dirancang pada tahap Designer. Konsep pemrograman yang digunakan pada MIT App Inventor adalah pemrograman EventHandler, dimana block-block program dibuat untuk mendefinisikan penanganan terhadap suatu kejadian (event) dari suatu komponen.

\subsection{Hasil Pengujian}

Tahap pengujian dilakukan setelah tahap proses pembuatan sistem yang di dalamnya terdapat pengkodean/pemrograman terhadap hasil tahap perancangan sistem/desain sistem. Pengujian dilakukan untuk memastikan bahwa aplikasi edutainment wawasan kebangsaan yang dibuat telah sesuai dengan yang direncanakan. Dalam penelitian ini tahap pengujian yang dilakukan yaitu pengujian pengujian runtime aplikasi. Adapun yang dimaksud pengujian runtime aplikasi adalah pengujian 
fungsionalitas dari aplikasi apakah dapat berjalan dengan baik sesuai dengan kebutuhan yang diharapkan.

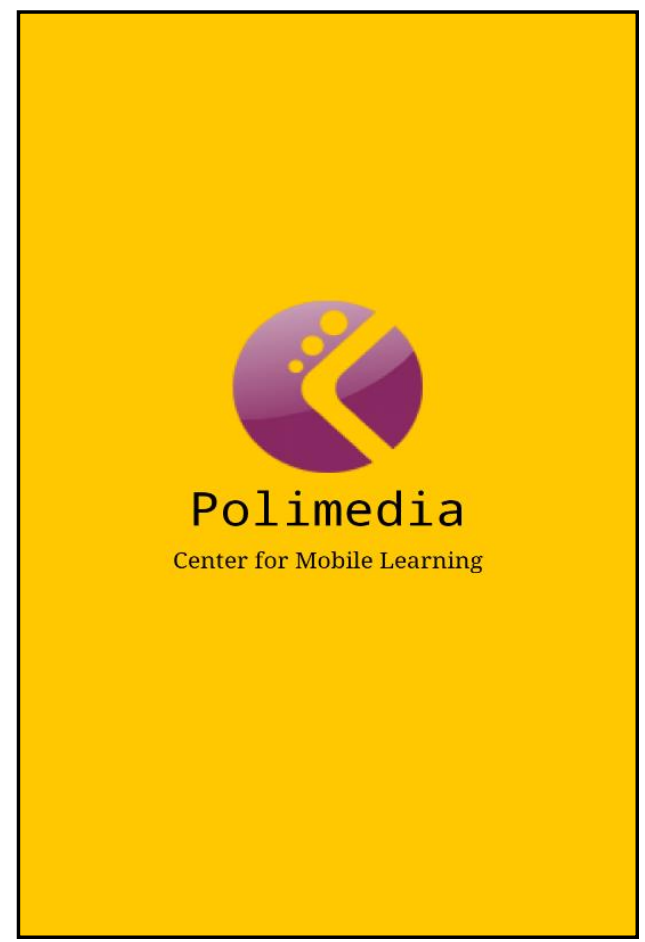

Gambar 2 Tampilan Splash Screen

Pada gambar 2 diperlihatkan screen capture hasil pengujian terhadap spash screen. Pada gambar 3 diperlihatkan tampilan help screen. Sedangkan pada gambar 4 diperlihatkan tampilan main screen dengan tombol level 1 sedang dalam kondisi aktif.

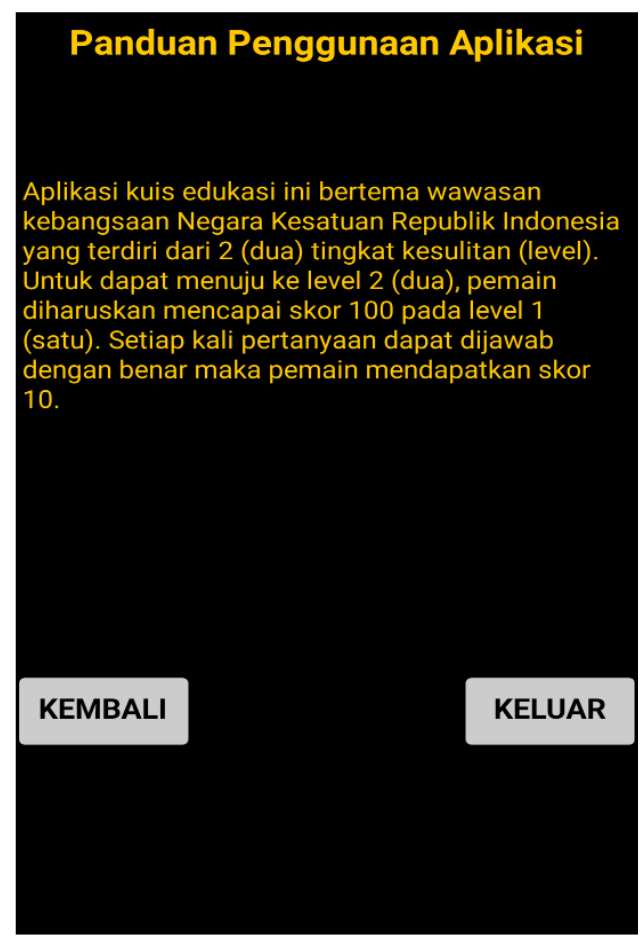

Gambar 3 Tampilan Help Screen

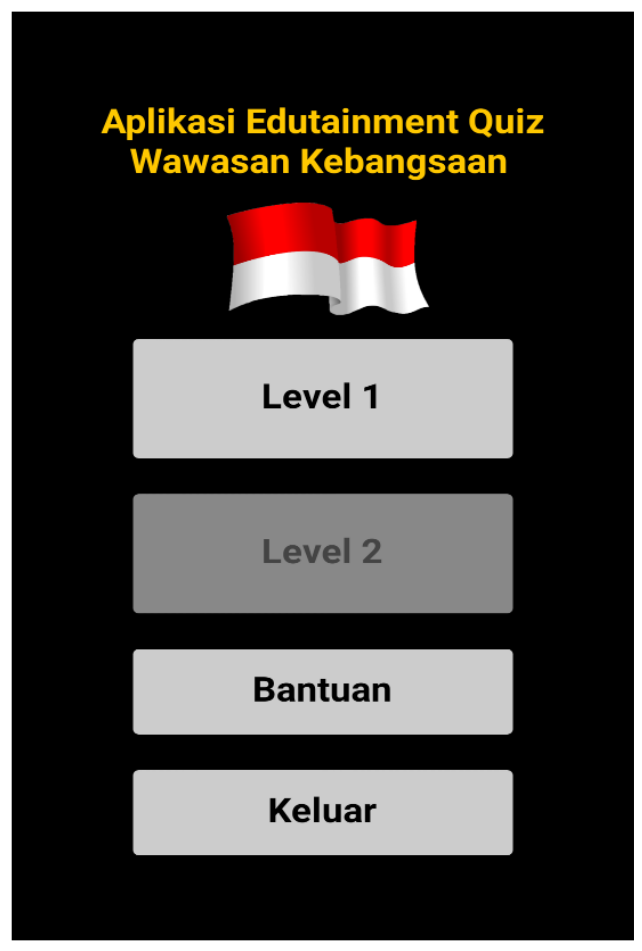

Gambar 4 Tampilan Main Screen dengan tombol level 1 aktif

Pada gambar 5 diperlihatkan screen capture hasil pengujian terhadap main screen dengan tombol level 2 sedang dalam kondisi aktif.
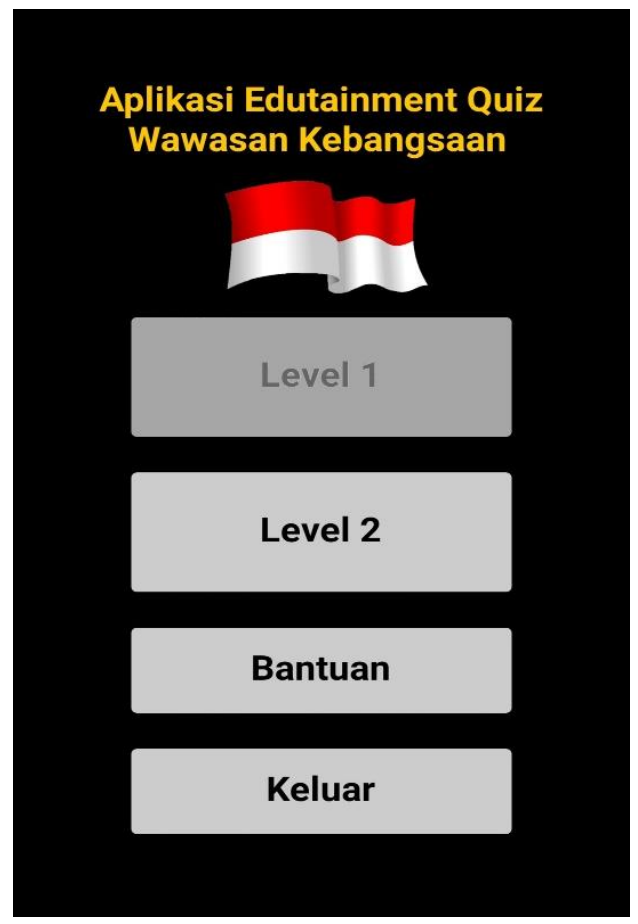

Gambar 5 Tampilan Main Screen dengan tombol level 2 aktif 


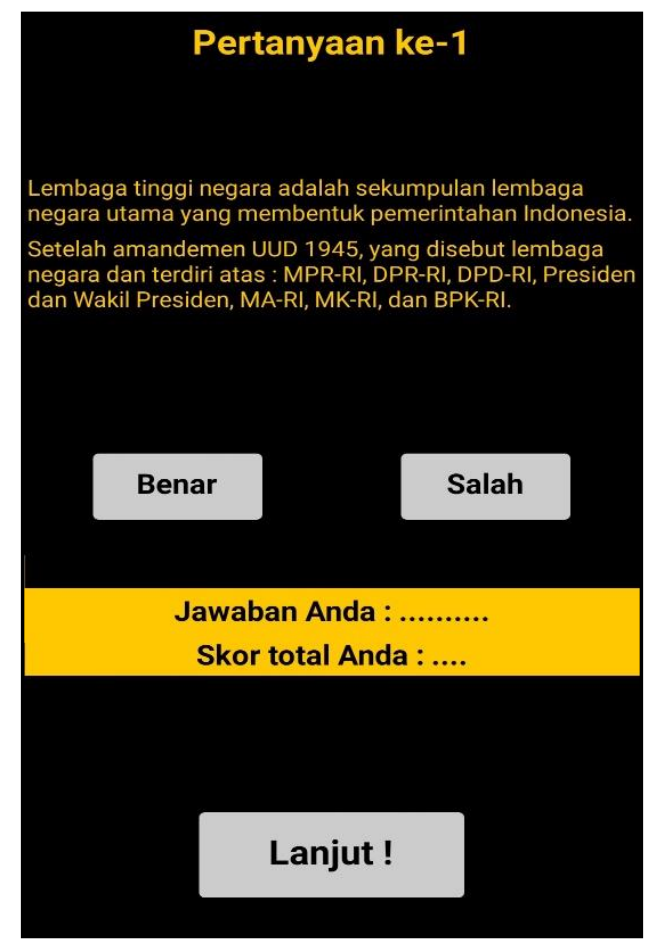

Gambar 6 Tampilan halaman pertanyaan kuis pada level 1

Pada gambar 6 diperlihatkan screen capture hasil pengujian terhadap halaman pertanyaan kuis pada level 1. Sedangkan gambar 7 diperlihatkan halaman pertanyaan kuis pada level 2 .

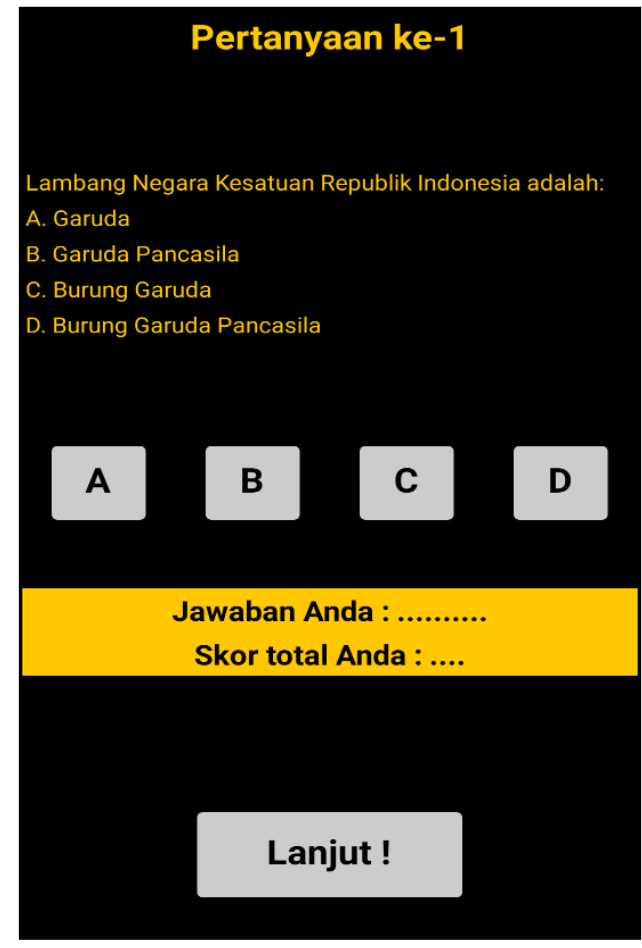

Gambar 7 Tampilan halaman pertanyaan kuis pada level 2

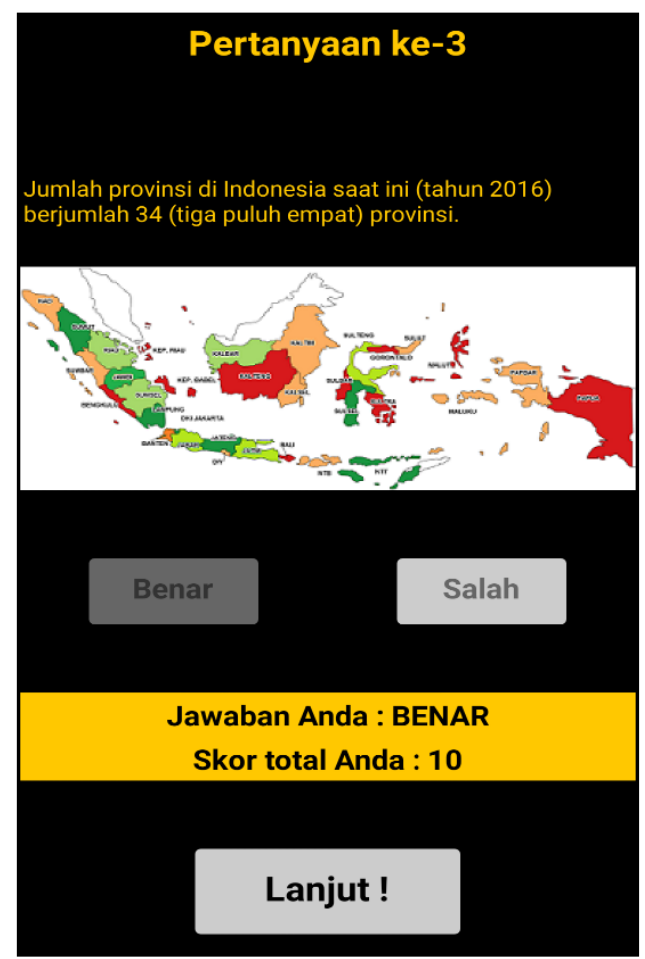

Gambar 8 Tampilan hasil ketika jawaban yang dipilih benar

Pada gambar 8 diperlihatkan screen capture hasil pengujian terhadap tampilan hasil ketika jawaban yang dipilih benar. Sedangkan gambar 9 diperlihatkan tampilan hasil ketika jawaban yang dipilih salah.

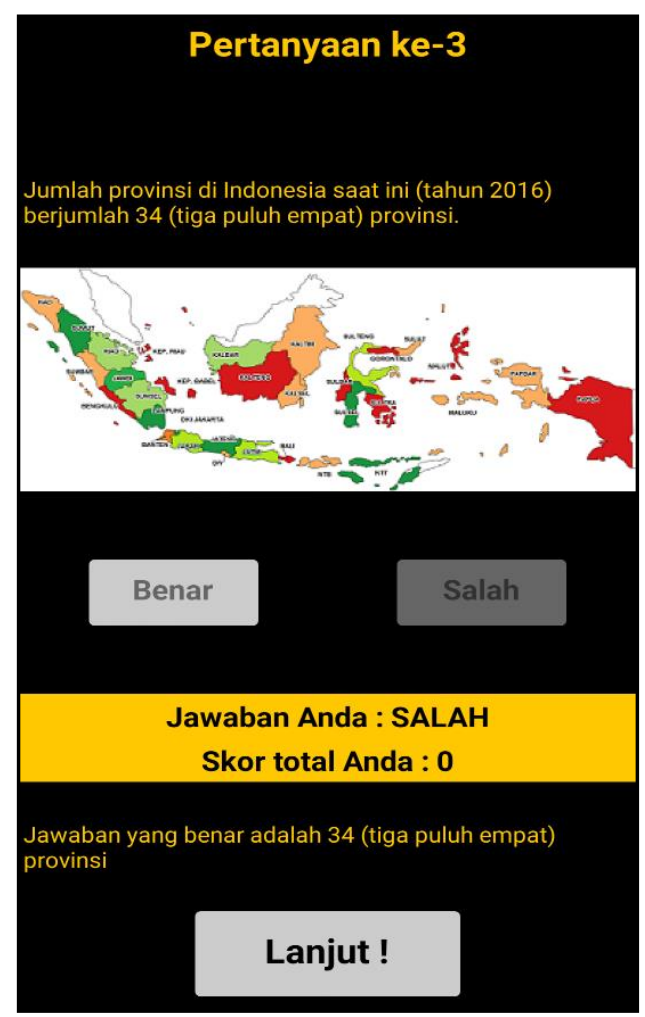

Gambar 9 Tampilan hasil ketika jawaban yang dipilih salah 


\section{KESIMPULAN DAN SARAN}

\subsection{Kesimpulan}

Aplikasi edutainment wawasan kebangsaan yang dibuat pada penelitian ini berupa aplikasi kuis dengan topik pertanyaan seputar wawasan dan pengetahuan tentang nasionalisme kebangsaan Negara Kesatuan Republik Indonesia (NKRI) mencakup konstitusi negara, sejarah bangsa, kekayaan budaya, dan kekayaan alam. Pertanyaan-pertanyaan yang ada di dalam aplikasi kuis berupa teks, gambar maupun suara.

Aplikasi kuis yang dibuat memiliki 2 (dua) tingkat kesulitan (level). Jenis pertanyaan pada tingkat kesulitan (level) 1 dirancang untuk memiliki tingkat kesulitan yang rendah dengan diberikan 2 (dua) buah kemungkinan jawaban yang benar yaitu menggunakan sistem pilihan ganda jawaban "Benar dan Salah". Sedangkan jenis pertanyaan pada tingkat kesulitan (level) 2 dirancang untuk memiliki tingkat kesulitan lebih tinggi dari pada tingkat kesulitan (level) 1 dengan diberikan 4 (empat) buah kemungkinan jawaban yang benar yaitu menggunakan sistem pilihan ganda jawaban “A, B, C, dan D”.

\subsection{Saran}

Pengembangan lebih lanjut terhadap penelitian ini dapat berupa peningkatan kuantitas dan kualitas dari pertanyaan-pertanyaan pada setiap levelnya. Selain itu lokasi penyimpanan pertanyaan dapat diletakkan secara terpusat dalam suatu sistem basis data dalam jaringan (online) sehingga pertanyaan yang ada pada aplikasi bersifat dinamis dan dapat terus ditambah dan diperbaharui.

\section{DAFTAR PUSTAKA}

[1.]Darcey, Lauren and Conder, Shane. 2010. Sams Teach Yourself Android Application Development in 24 Hours. Sams Publishing.

[2.]Fling, Brian. 2009. Mobile Design and Development. O'Reilly Media.

[3.] Safaat, Nazarudin. 2011. Pemrograman Aplikasi Mobile Smartphone dan Tablet PC Berbasis Android. Penerbit Informatika. Bandung.

[4.] Sugiyono. 2008.

Metode Penelitian Kunatitatif Kualitatif dan Research \& Development.

Alfabeta.Bandung.

[5.]Tantra, Rudi. 2012. Manajemen Proyek Sistem Informasi. Penerbit Andi.

Yogyakarta.

[6.] Tim Indonesia Design Power. 2008. Pengembangan Ekonomi Kreatif Indonesia 2025. Departemen Perdagangan Republik Indonesia. Jakarta.
[7.] Wahana Komputer. 2013. Pemrograman Android dengan App Inventor. Penerbit Andi. Yogyakarta.

[8.]Wolber, David and Abelson, Hal. 2011. App Inventor: Create Your Own Android Apps. O'Reilly Media.

\section{BIODATA PENULIS}

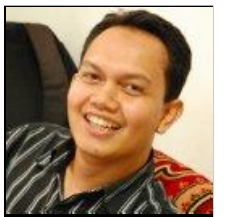

\section{Nofiandri Setyasmara}

Dosen pada Jurusan Desain Grafis, Politeknik Negeri Media Kreatif 